\title{
PENGARUH LAYANAN KONSELING KELOMPOK TEKNIK MODELLING TERHADAP EMPATI PADA TEMAN SEBAYA SISWA KELAS XI IPA 1 MAN 2 MODEL MEDAN T.A 2016/2017
}

\author{
Asiah M. Pd \\ Oski Putri Iskandar \\ Jurusan Bimbingan dan Konseling \\ Fakultas Ilmu Pendidikan, Universitas Negeri Medan
}

\begin{abstract}
Abstrak
Penelitian ini bertujuan untuk mengetahui apakah ada pengaruh layanan konseling kelompok teknik Modelling terhadap empati pada teman sebaya siswa kelas XI IPA 1 MAN 2 Model Medan T.A 2016/2017. Penelitian ini dilaksanakan pada bulan Juli s/d September 2017. Penelitian ini merupakan penelitian kuantitatif dengan Pre experimental design dengan jenis Pre test-post test one group design. Populasi dalam penelitian ini adalah seluruh siswa kelas XI IPA 1 MAN 2 Model Medan. Sampel ditarik dengan menggunakan metode purposive sampling sebanyak 8 orang yang berasal dari kelas XI IPA 1 sampel yang homogen. Data penelitian ini dikumpulkan dengan menggunakan angket empati pada teman sebaya berjumlah 32 item pernyataan yang telah valid dan reliabel kemudian data dianalisis menggunakan uji Wilcoxon. Dari analisis data diperoleh $J$ hitung $=16,5$ dengan $\alpha=0,05$, adapun $J$ tabel $=4$. Dari data tersebut terlihat bahwa $J_{\text {hitung }}>J_{\text {Tabel }}$ dimana $16,5>4$. Artinya hipotesis diterima. Data pre-test empati pada teman sebaya diperoleh skor rata-rata 61, sedangkan data post-test empati pada teman sebaya diperoleh skor rata-rata sebesar 101. Artinya skor rata-rata siswa setelah mendapat layanan konseling kelompok teknik Modelling lebih tinggi daripada sebelum mendapat layanan konseling kelompok teknik Modelling. Layanan konseling kelompok teknik Modelling memberikan kontribusi sebesar 65,5\% terhadap peningkatan empati pada teman sebaya siswa kelas XI IPA 1 MAN 2 Model Medan T.A 2016/2017.

Kata Kunci $\quad$ : Konseling Kelompok; Modelling; Empati, Teman Sebaya.
\end{abstract}

\section{PENDAHULUAN}

Sebagai seorang remaja yang berada di jenjang pendidikan SMA, siswa dituntut untuk memiliki sikap empati yang baik sebagaimana Hurlock (dalam Asih, 2010: 35) menyatakan bahwa empati seharusnya sudah dimiliki oleh remaja, karena kemampuan berempati sudah mulai muncul pada masa kanak-kanak awal.

Empati yang paling penting bagi remaja adalah empati pada teman sebaya karena seorang remaja sangat membutuhkan peran teman sebayanya sebagai sumber dukungan sosial ketika sedang menghadapi masalah sebagaimana menurut Singgih D. Gunarsa (dalam Hartinah, 2008: 68) menyatakan bahwa kebanyakan remaja menemukan jalan keluar dari kesulitannya setelah mereka berkumpul dengan rekan sebayanya untuk melakukan kegiatan bersama. Selain itu, papalia et all (2013: 95) menyatakan bahwa kelompok sebaya adalah sumber kasih sayang, simpati, pengertian, dan tuntutan moral, serta sarana untuk mencapai otonomi dan kemandirian dari orangtua. Dengan demikian empati dari teman sebaya sangat dibutuhkan oleh remaja. 
Menurut Hurlock (dalam Asih, 2010: 34) mengungkapkan bahwa empati adalah kemampuan seseorang untuk mengerti tentang perasaan dan emosi orang lain serta kemampuan untuk membayangkan diri sendiri di tempat orang lain.

Menurut Eisenberg (dalam Aulia, 2016: 20) dalam proses berempati, individu melibatkan aspek afektif dan kognitif. Aspek afektif merupakan kecenderungan seseorang untuk mengalami perasaan emosional orang lain yaitu ikut merasakan ketika orang lain merasa sedih, menangis, terluka, menderita bahkan disakiti sedangkan aspek kognitif dalam empati difokuskan pada proses intelektual untuk memahami perspektif orang lain dengan tepat dan menerima pandangan mereka, misalnya membayangkan perasaan orang lain ketika marah, kecewa, senang, memahami keadaan orang lain dari cara berbicara, dari ekspresi wajah dan cara pandang dalam berpendapat.

Namun kenyataannya di lapangan, banyak siswa yang belum mampu berempati pada teman sebayanya. Berdasarkan data yang diperoleh peneliti di lapangan dari hasil Alat ungkap masalah Umum (AUM-UMUM) diperoleh bahwa 19 dari 32 siswa atau 59\% siswa mengalami masalah dalam hubungan sosial (HSO) pada item nomor 151 yaitu kurang peduli terhadap orang lain. Dengan demikian dapat disimpulkan bahwa masih banyak siswa yang belum mampu berempati dengan baik.

Hal itu ditandai dengan ketidakpedulian siswa ketika temannya menghadapi masalah. Mereka tidak mampu merasakan apa yang sedang dirasakan oleh temannya. Mereka seolah menutup mata dan mengabaikan hal tersebut. Bahkan yang lebih menyedihkan ada diantara siswa yang bersikap agresif dan menyakiti hati teman sebayanya sehingga temannya menjadi siswa yang terisolir.

Ada juga sebagian siswa yang mau memberikan pertolongan kepada teman sebayanya namun mempertimbangkan motif dalam diri si penolong, misalnya untuk mengharapkan imbalan dari orang yang telah ditolong, bukan karena adanya rasa empati yang mendasari (Wahyuningsih, dalam Andromeda 2014: $1)$.

Adapun teknik modelling adalah teknik yang dilakukan dengan mengamati seorang model dan kemudian diperkuat untuk mencontoh tingkah laku sang model (Corey, 2013: 221). Dengan memperagakan perilaku model, siswa dapat belajar bagaimana cara berempati pada teman sebayanya. 
Berdasarkan uraian di atas, peneliti tertarik untuk mengadakan penelitian dengan judul "Pengaruh Layanan Konseling Kelompok Teknik Modelling Terhadap Empati pada teman sebaya Siswa Kelas XI IPA1 MAN 2 Model Medan T.A 2016/2017”.

\section{KAJIAN PUSTAKA}

\section{Empati}

Menurut Hurlock (dalam Asih, 2010: 35) mengungkapkan bahwa empati adalah kemampuan seseorang untuk mengerti tentang perasaan dan emosi orang lain serta kemampuan untuk membayangkan diri sendiri di tempat orang lain. Byrne \& Baron (dalam Auliyah, 2016: 20) yang menyatakan bahwa empati merupakan kemampuan individu untuk dapat merasakan perasaan atau pengalaman orang lain. Oleh karena itu, dengan mempunyai sikap empati seorang individu dapat berbagi perasaan dengan orang lain dalam suasana suka maupun duka, kesediaan memberikan bantuan kepada orang lain baik materiil maupun moril dan juga kesediaan untuk bekerjasama dengan orang lain demi tercapainya suatu tujuan. Dari beberapa pendapat para ahli diatas dapat disimpulkan bahwa empati adalah kemampuan seseorang untuk ikut merasakan perasaan orang lain, dibangun berdasarkan kesadaran diri, peka terhadap bahasa isyarat teman, dan mampu mengambil peran ketika teman sebaya membutuhkan bantuan baik dukungan moriil maupun materiil. Baron dan Byrne (dalam Asih, 2010: 36) menyatakan bahwa aspek-aspek empati adalah 1) Kognitif yaitu individu yang memiliki kemampuan empati dapat memahami apa yang orang lain rasakan dan mengapa hal tersebut dapat terjadi pada orang tersebut. 2) Afektif yaitu individu yang berempati merasakan apa yang orang lain rasakan.

Adapun yang menjadi indikator dari penelitian ini diambil dari ciri-ciri orang yang memiliki empati yang tinggi menurut Depag RI (dalam Sam, 2013: 45) yaitu: ikut merasakan (sharing feeling) bagaimana perasaan orang lain, dibangun berdasarkan kesadaran sendiri, peka terhadap bahasa isyarat karena emosi, dan mengambil peran (role ta king).

Beberapa faktor yang mempengaruhi empati menurut Klein \& Hodges (dalam Taufik, 2012: 119) adalah sebagai berikut: gender, faktor kognitif, faktor sosial, dan status sosial ekonomi

Empati juga memiliki beberapa proses, menurut Davis (dalam Taufik, 2012: 53) Terdapat Tiga jenis proses empati, yaitu: a) Non cognitive processes. Pada proses ini terjadinya empati disebabkan oleh proses-proses non kognitif, artinya tanpa memerlukan pemahaman terhadap situasi yang terjadi. 
b) Simple cognitive processes. Pada jenis empati hanya membutuhkan sedikit proses kognitif. c) Advance cognitive processes. Berbeda hal nya dengan proses yang pertama dan kedua, pada proses ini kita dituntut untuk mengarahkan kemapuan kognitif kita.

\section{Teman Sebaya}

Teman sebaya menurut Padmomartono (2014: 66) adalah anak atau remaja yang kurang lebih berada pada taraf usia yang sama atau berada pada taraf perkembangan yang sama pula. Sedangkan Menurut Santrock (dalam Wicaksono, 2014: 15) teman sebaya adalah orang dengan tingkat umur dan kedewasaan yang kira-kira sama.

Dari beberapa pendapat tersebut dapat disimpulkan bahwa teman sebaya adalah individu-individu yang memiliki usia dan perkembangan yang relatif sama.

Adapun fungsi teman sebaya menurut Vembriarto (dalam Wicaksono, 2014: 17) adalah sebagai berikut:a) Tempat belajar bergaul dengan sesamanya b) Tempat mempelajari kebudayaan masyarakatnya c) Mereka belajar bagaimana menjadi manusia yang baik sesuai dengan gambaran dan cita-cita masyarakatnya, tentang kejujuran, keadilan, kerja sama, tanggung jawab; tentang peranan sosialnya sebagai pria atau wanita; memperoleh berbagai macam informasi, meskipun kadang-kadang informasi yang menyesatkan, serta mempelajari kebudayaan khusus masyarakatnya yang bersifat etnik, keagamaan, kelas sosial, dan kedaerahan.

Berdasarkan teori diatas dapat disimpulkan bahwa empati pada teman sebaya adalah kemampuan seseorang untuk mengerti tentang perasaan, pengalaman dan emosi serta kemampuan untuk membayangkan diri sendiri di posisi teman seusianya dalam suasana suka maupun duka sehingga tercipta kesediaan memberikan bantuan baik materiil maupun moril.

\section{Pengertian Konseling Kelompok}

Konseling adalah suatu rangkaian pertemuan langsung dengan individu yang ditujukan pada pemberian bantuan kepadanya untuk dapat menyesuaikan diri secara lebih efektif dengan dirinya sendiri dan dengan lingkungannya (Daniel, dalam Prayitno, 2004)

Prayitno (2004: 105) menyatakan bahwa konseling adalah proses pemberian bantuan yang dilakukan melalui wawancara konseling oleh seorang ahli (disebut konselor) kepada individu yang sedang mengalami suatu masalah (disebut klien) yang bermuara pada teratasinya masalah yang dihadapi klien.

Sedangkan kelompok adalah sekumpulan unit yang mempunyai 
persamaan umum dan saling berinteraksi antara anggotanya dengan cara sedemikian rupa sehingga setiap unit diubah oleh anggota kelompoknya (Wibowo 2005: 14). Kelompok bukan hanya kumpulan dari beberapa orang saja melainkan adanya unsur-unsur yang harus terpenuhi dalam membentuk sebuah kelompok. unsur-unsur tersebut yang paling pokok menyangkut tujuan, keanggotaan dan kepemimpinan, serta aturan yang diikuti (Prayitno 2004: 308)

Dari beberapa pendapat ahli diatas dapat diambil kesimpulan bahwa konseling kelompok adalah proses bantuan yang diberikan oleh konselor kepada konseli dengan memanfaatkan dinamika kelompok untuk membahas dan menemukan solusi atas suatu masalah secara bersama-sama sehingga konseli mencapai pertumbuhan dan perkembangan yang lebih optimal.

\section{Teknik Modelling}

Modelling (peniruan melalui penokohan) merupakan salah satu teknik dalam pedekatan behavioristik yang menekankan pada prosedur belajar. Behavioristik adalah suatu pandangan ilmah tentang tingkah laku manusia. Menurut Natawidjaja (dalam Kurnanto, 2013: 62) pendekatan behavioristik adalah perilaku, kognisi, perasaan bermasalah itu semuanya terbentuk karena dipelajari, dan itu semua bisa diubah dengan proses belajar yang baru atau belajar kembali. Pada prinsipnya pendekatan behavioristik itu sendiri bertujuan untuk memperoleh perilaku baru, mengeliminasi perilaku lama yang merusak diri dan memperkuat serta mempertahankan perilaku yang diinginkan yang lebih sehat.

Dengan demikian, modelling adalah teknik peniruan melalui penokohan baik dari model hidup atau nyata dan model dari media seperti video, gambar, dan audio.

Menurut Corey (2013: 9), tujuan teknik modelling dalam pendekatan behavioristik ini adalah merubah perilaku dengan mengamati model yang akan ditiru agar konseli memperkuat perilaku yang sudah terbentuk.

\section{METODE PENELITIAN}

Desain yang digunakan dalam penelitian ini adalah One group pre-test post-test design yaitu dengan melakukan tes sebelum eksperimen (O1) dan melakukan tes sesudah eksperimen (O2). Populasi Penelitian ini adalah seluruh siswa-siswi kelas XI IPA 1 MAN 2 Model Medan tahun ajaran 2016/2017 yang berjumlah 30 orang. Adapun sampel penelitian ini yang diperoleh dari kelas XI IPA 1 berjumlah 30 orang yang diberi angket tentang empati pada teman sebaya. Setelah angket dianalisis maka yang 
mendapat skor yang terendah yang akan dijadikan sampel dalam penelitian ini yaitu sebanyak 8 orang.

\section{HASIL DAN PEMBAHASAN}

Hasil analisa data yang diperoleh dalam penelitian ini adalah nilai $\mathrm{J}$ hitung $=16,5$ dengan $\alpha=0,05$ dan $n=8$. Maka berdasarkan daftar, $\mathrm{J}$ tabel $=4$. Dari data tersebut terlihat bahwa Jhitung > JTabel dimana $16,5>4$. Artinya hipotesis diterima. Data pre-test diperoleh rata-rata 61, sedangkan data post-test setelah diberikan layanan konseling kelompok teknik modelling diproleh rata-rata sebesar 101 Artinya skor rata-rata siswa setelah mendapat layanan konseling kelompok teknik modelling lebih tinggi daripada sebelum mendapat layanan konseling kelompok teknik modelling. Perubahan peningkatan interval empati pada teman sebaya setelah diberi layanan konseling kelompok teknik modelling sebesar $65,5 \%$.

Berdasarkan data post-test yang diperoleh dari hasil penelitian dengan jumlah responden 8 orang, maka diperoleh jumlah nilai sebesar 808 , rata-rata $=101$, standar deviasi $=6,8$ skor maksimal $=111$, skor minimal $=91$.

Hasil perhitungan data post-test yang diperoleh dapat dilihat pada tabel berikut:
Tabel 1. Hasil Post-Test Empati Pada Teman Sebaya

\begin{tabular}{|l|l|l|}
\hline Responden & Skor & Kategori \\
\hline MF & 111 & Tinggi \\
\hline MR & 102 & Tinggi \\
\hline FM & 107 & Tinggi \\
\hline NA & 91 & Sedang \\
\hline SR & 103 & Tinggi \\
\hline MZ & 104 & Tinggi \\
\hline SA & 96 & Sedang \\
\hline YH & 94 & Sedang \\
\hline Jumlah & $\mathbf{8 0 8}$ & \\
\hline Nilai Tertinggi & $\mathbf{1 1 1}$ & \\
\hline $\begin{array}{l}\text { Nilai } \\
\text { Terendah }\end{array}$ & $\mathbf{9 1}$ & \\
\hline Rata-Rata & $\mathbf{1 0 1}$ & \\
\hline
\end{tabular}

Setelah diberikan layanan konseling kelompok teknik Modelling, maka diperoleh hasil penelitian dengan jumlah responden 8 orang yaitu responden dengan 3 kategori sedang dan 5 kategori tinggi.

Berdasarkan tabel di atas dapat dilihat bahwa rata-rata data post-test lebih tinggi daripada rata-rata pre-test, yaitu $101>61$. Jadi dapat disimpulkan bahwa ada peningkatan empati pada teman sebaya dari yang rendah menjadi tinggi setelah diberikan layanan konseling kelompok teknik Modelling dengan perubahan interval sebesar $65,5 \%$. Hasil perbandingan Pre-test dan Post-test dapat dilihat pada tabel dibawah ini:

Tabel 2. Data Hasil Angket Pre-Test dan Angket Post-Test

\begin{tabular}{|c|c|c|r|r|}
\hline Responden & \multicolumn{1}{|l|}{$\begin{array}{l}\text { Skor } \\
\text { Pre-Test }\end{array}$} & $\begin{array}{l}\text { Skor } \\
\text { Post-Test }\end{array}$ & $\begin{array}{l}\text { Selisih } \\
\text { Skor }\end{array}$ & \multicolumn{1}{c|}{} \\
\hline MF & 64 & 111 & 47 & $14,7 \%$ \\
\hline MR & 63 & 102 & 39 & $12,1 \%$ \\
\hline FM & 62 & 107 & 45 & $14 \%$ \\
\hline NA & 61 & 91 & 30 & $9,3 \%$ \\
\hline SR & 61 & 103 & 42 & $13,1 \%$ \\
\hline MZ & 60 & 104 & 44 & $13,7 \%$ \\
\hline SA & 59 & 96 & 37 & $11,5 \%$ \\
\hline YH & 58 & 94 & 36 & $11,2 \%$ \\
\hline Jumlah & $\mathbf{4 8 8}$ & $\mathbf{8 0 8}$ & 320 & \\
\hline Nilai Tertinggi & $\mathbf{6 4}$ & $\mathbf{1 1 1}$ & & \\
\hline Nilai Terendah & $\mathbf{5 8}$ & $\mathbf{9 1}$ & & \\
\hline Rata-rata & $\mathbf{6 1}$ & $\mathbf{1 0 1}$ & & \\
\hline
\end{tabular}


Dapat dilihat persentase peningkatan empati pada teman sebaya setelah diberikan layanan konseling kelompok teknik modelling yaitu, MF memperoleh selisih skor 47 dengan persentase sebesar 14,7 persen, MR memperoleh selisih skor 39 dengan persentase 12,1 persen, FM memperoleh selisih skor 45 dengan persentase 14 persen, NA memperoleh selisih skor 30 dengan persentase 9,3 persen SR memperoleh selisih skor 42 dengan persentase 13,1 persen $\mathrm{MZ}$ memperoleh selisih skor 44 dengan persentase 13,7 persen, SA memperoleh selisih 37 dengan persentase 11,5 persen, YH memperoleh selisih skor 36 dengan persentase 11,2 persen.

Hasil perbandingan Pre-test dan Posttest juga dapat dilihat pada grafik dibawah ini :

Grafik 1. Data Hasil Angket Pre-Test dan Angket Post-Test

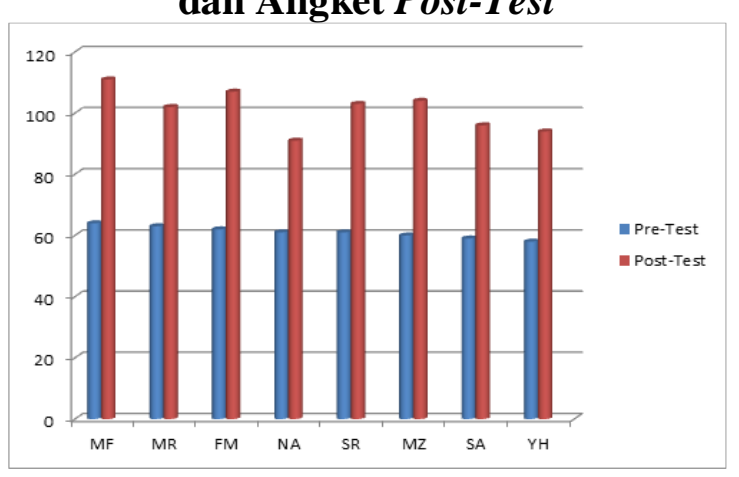

Keberhasilan dalam layanan konseling kelompok teknik modelling ini dapat dilihat dari peningkatan skor yang diisi oleh anggota kelompok. Anggota kelompok pada awalnya berada pada kategori rendah sebanyak 8 orang yaitu, MF 64, MR 63, FM 62, NA 61, SR 61, MZ 60, SA 59 dan YH 58, mengalami peningkatan sehingga mencapai kategori sedang yaitu 3 orang dengan inisial NA 91, SA 96, dan YH 94 sedangkan kategori tinggi sebanyak 5 orang dengan inisial MF 111, MR 102, FM 107, SR 103 dan MZ 104. Selain itu terlihat dari respon mereka terhadap kegiatan layanan konseling kelompok yang semakin aktif dan semakin antusias untuk meningkatkan empati pada teman sebaya.

\section{PENUTUP}

\section{Kesimpulan}

Hasil analisa data yang diperoleh dalam penelitian ini adalah nilai hitung $=16,5$ dengan $\alpha=0,05$ dan $n=8$. Maka berdasarkan daftar, $\mathrm{J}$ tabel $=4$. Dari data tersebut terlihat bahwa Jhitung > JTabel dimana $16,5>4$. Artinya hipotesis diterima. Data pre-test diperoleh rata-rata 61, sedangkan data post-test setelah diberikan layanan konseling kelompok teknik Modelling diproleh rata-rata sebesar 101. Artinya skor rata-rata siswa setelah mendapat layanan konseling kelompok teknik Modelling lebih tinggi daripada sebelum mendapat layanan konseling kelompok teknik Modelling. Perubahan peningkatan interval empati siswa dikelas setelah diberi layanan konseling kelompok teknik modelling sebesar $65,5 \%$. Hal ini 
menunjukkan bahwa hipotesis dapat diterima.

\section{Saran}

Adapun saran yang dapat dikemukakan peneliti adalah:

Diharapkan kepada Kepala Sekolah lebih memberikan fasilitas, sarana dan prasarana kegiatan layanan bimbingan dan konseling di sekolah agar tujuan yang diharapkan dapat tercapai secara optimal.

Guru pembimbing diharapkan menindaklanjuti kegiatan layanan bimbingan dan konseling kelompok untuk penyelesaian masalah yang lebih lanjut.

Bagi siswa/i yang masih memiliki empati yang rendah seharusnya lebih giat untuk menunjukkan kemampuan positif apa saja yang dimilikinya dan mengikuti layanan bimbingan konseling yang diadakan guru pembimbingnya.

Diharapkan bagi peneliti lain dapat dijadikan sebagai bahan masukan dan sumber referensi dalam penelitian di bidang yang sama terutama untuk menumbuhkembangkan kemampuan dan keterampilan meneliti serta menulis.

\section{DAFTAR PUSTAKA}

Auliyah, Alan dan Elia Flurentin. 2016. Efektifitas Penggunaan Media Film Untuk Meningkatkan Empati Siswa Kelas Vii Smp. Jurnal Kajian Bimbingan dan Konseling Vol 1, No. 1, 2016, hlm. 19-26 (Online) Tersedia
Downloads\Documents\5535-48161-SM.pdf diakses pada 12 April 2017

Corey, Gerald. 2013. Teori Dan Praktik Konseling Dan Psikoterapi. Terj. E. Koswara, Bandung: Pt Refika Aditama.

Hartinah, Siti. 2008. Perkembangan Peserta Didik. Bandung: PT Refika Aditama.

Padmomartono, Sumarjono. 2014. Konseling Remaja. Yogyakarta: Penerbit Ombak.

Prayitno dan Erman Amti. 2004. DasarDasar Bimbingan dan Konseling. Jakarta: PT. Rineka Cipta.

Saam, Zulfan. 2013. Psikologi Konseling. Jakarta: Rajawali Pers.

Taufik, 2012. Empati Pendekatan Psikologi Sosial. Jakarta: Rajawali Pers.

Widiarsono, Wahyu. 2010. Skala Pengembangan Psikologi: Lima kategori respons ataukah empat kategori respons?. Fakultas Psikologi UGM. (Online) tersedia di http://widhiarso.staff.ugm.ac.id/files/ 2___skala_psikologi.pdf diakses pada 22 Desember 2017.

Wicaksono, Okky. 2014. Hubungan Antara Pergaulan Teman Sebaya Dengan Prestasi Belajar Siswa Kelas $V \quad S d$ Gugus Jenderal Sudirman, Kecamatan Sempor, Kabupaten Kebumen. Skripsi Fakultas Ilmu Pendidikan Universitas Negeri Yogyakarta. (Online). 